\title{
4. Raising the Standards of Family Life: Ginling Women's College and Christian Social Service in Republican China
}

\author{
Helen M. Schneider \\ Virginia Tech, USA
}

\section{Introduction}

In the past the greatest fault of Ginling Women's College was in only thinking of how fine, how fine, Ginling was in lifeless reading of a few books and engaging in so-called social service. But we didn't know whom we were trying to reach with our service, nor what goal we were trying to achieve. Then doing only a few tiny superficial things was counted as social service. Therefore, when I think of all that in the past, I feel very ashamed.

Wu Yifang, 1973

Between 1928 and $1951 \mathrm{Wu}$ Yifang served as the president of the Protestant missionary-founded Ginling Women's College. ${ }^{2}$ During their 1952 reshuffle of higher education, the new Communist regime organised Ginling out of existence. Wu remained in leadership positions during the Maoist period. ${ }^{3} \mathrm{Her}$ condemnation of Ginling's social service work shows that she embraced the Communist critique of Christian education as an insidious form of what has been termed cultural imperialism, or what she called "cultural aggression." ${ }^{4}$ Wu held that social service only temporarily and superficially ameliorated the distress of the working and peasant masses, and thereby delayed a political revolution which would bring about real change. Despite these later criticisms, during

1 Chao Hao-sheng, typescript of interview of Yi-fang Wu, 1973, PHA, RG 279-1-5, p. 12.

2 For much of its history, Ginling Women's College was known as Jinling nüzi wenli xueyuan 金陵女子文理 学院 in Chinese. Here I retain the original Romanisation-Ginling. For histories see Jin Feng, The Making of a Family Saga: Ginling College, Albany: State University of New York Press, 2009; Matilda C. Thurston and Ruth Chester, Ginling College, New York: United Board for Christian Colleges in China, 1955.

3 For a biography of Wu, see Mary Jo Waelchli, "Wu Yifang: abundant life in training women for service," in Salt and Light: Lives of Faith that Shaped Modern China, ed. Carol Lee Hamrin with Stacy Bieler, Eugene OR: Pickwick Publications, 2009, pp. 152-70.

4 Chao Hao-sheng, typescript of interview of Yi-fang Wu, pp. 5-6. 
much of the Republican period (1911-1949) Wu devoted herself to preparing college-educated women for service - to China, to Chinese women and for God. ${ }^{5}$ This preparation was not just through reading "lifeless" books but through learning foreign knowledge, designing programs to help raise living standards and engaging in social service to improve Chinese families.

For several decades much has been written about the role of women missionaries as agents of cultural imperialism, about interpreters of foreign culture or as teachers of new forms of domesticity. ${ }^{6}$ More recent scholarship on China has looked at the first generation of local Christian women and their role in transforming the church from the nineteenth to the early twentieth century. ${ }^{7}$ Some of this work shows how describing missionary work with women as cultural imperialists has ignored the crucial role of Chinese women in shaping their own society. ${ }^{8}$ This chapter considers this issue in a slightly later historical period by focusing on the 1930s and the 1940s. What happened once China's Christian colleges had trained a generation of Chinese women? How did they understand concepts of service and their roles in transforming China? To answer these questions, this chapter looks at the social service work of Ginling College, a Christian women's college established by missionaries in 1913.

Ginling's work occurred at a time of intensive nation building, when the Qing dynasty (1644-1911) social and political order had crumbled and, when after 1927, the Communist and the Nationalist party (the Guomindang) struggled for ascendancy. $\mathrm{Wu}$ and other Chinese women worked hard to figure out ways to provide meaningful service to the developing nation of China. The service work that occurred under Wu's leadership was a result of processes of cultural exchange and transformation rather than one of Euro-American cultural imperialism and a Western imposition of knowledge. Educated Chinese women-as students, graduates, and leaders of Ginling - indigenised or localised foreign knowledge about how to reform families originally learned from their missionary teachers.

5 Ryan Dunch has pointed out that "a common thread running through Protestant women's roles was an ideology of service, whether to the church, to family, to Chinese women, or to nation." See Ryan Dunch, "'Mothers to our country': conversion, education, and ideology among Chinese Protestant women, 18701930," in Pioneer Chinese Christian Women: Gender, Christianity, and Social Mobility, ed. Jessie G. Lutz, Bethlehem: Lehigh University Press, 2010, pp. 324-50.

6 For an overview of this literature see Barbara Reeves-Ellington, "Women, Protestant missions, and American cultural expansion, 1800 to 1838: a historiographical sketch," Social Sciences and Missions 24 (2011): 190-206.

7 Jessie G. Lutz (ed.), Pioneer Chinese Christian Women: Gender, Christianity, and Social Mobility, Bethlehem: Lehigh University Press, 2010.

8 Ryan Dunch has discussed this problem for scholars when looking at missionary work in China. See Dunch, "Beyond cultural imperialism: cultural theory, Christian missions, and global modernity," History and Theory 41(3) (October 2002): 301-25. Margo S. Gewertz has pointed out the need to look at Chinese Christian women outside of the "analytic frame of cultural imperialism." Gewertz, "Women and Christianity in rural North Henan, 1890-1912," in Pioneer Chinese Christian Women: Gender, Christianity, and Social Mobility, ed. Lutz, Bethlehem: Lehigh University Press, 2010, pp. 199-213. 
Chinese women took up foreign missionary ideas about women's roles in transforming families, as well as disciplinary training to do so, and developed programs they felt would meet China's needs.

In this chapter I will show some of the ways that missionary ideas about service and domestic improvement were localised and indigenised in China through an examination of Ginling's social service under the direction of Wu. I look particularly closely at Ginling's development of rural service stations after 1938, when social service shifted from foreign missionary leadership to an almost complete indigenisation of programs under Chinese women's leadership during the Sino-Japanese war. I draw heavily on the professional correspondence of $\mathrm{Wu}$ and Ginling graduates found in archives in the United States and China. These materials show how concepts of rural and domestic improvement circulated between the two countries, and eventually came to be transformed by Chinese women.

An examination of Ginling's rural service shows that in some respects $\mathrm{Wu}$ was not far off the mark. From the 1930s on, Ginling women assumed educated elite superiority and accepted some gender roles learned from both historical precedent and from their missionary teachers. Ginling women aimed to reconfigure ideas of domestic improvement, or reform of China's family and home life, and transferred the standards they deemed modern to the "backward" women of China. They positioned themselves as arbiters of modernity because they had scientific, professional training and, as women, they had an affinity for working with women and children. Through their social service, Ginling women created a sphere of action for educated Chinese women.

In their efforts to save China through service, Ginling women furthered discourses of Chinese backwardness and followed what they thought were superior forms of reform from the West. In some ways, they were practising a form of selfOrientalism. Arif Dirlik suggests self-Orientalism should be partly seen as "how Euro-American images of Asia may have been incorporated into self-images of Asians." ${ }^{9}$ Protestant missionaries over the course of the nineteenth and into the twentieth century saw Chinese society as one with a multitude of problems. One, of course, was that China was a heathen land. But beyond that, they believed certain social practices, such as foot binding and the keeping of concubines, must necessarily be reformed. Protestant missionaries presented the "uplift of Chinese women" to the Chinese as a crucial component of Christianity, and it became a measure by which the Chinese were judged. ${ }^{10}$ It was also a standard by which Chinese judged themselves. The "backwardness" of women became an

9 Arif Dirlik, "Chinese history and the question of orientalism," History and Theory 35(4) (December 1996): 96-118, p. 104.

10 Dunch, "“Mothers to our country,"' p. 325. 
important trope for Chinese reformers in explaining why China lagged behind other nations in terms of social, economic and political development during the course of the nineteenth and early twentieth centuries.

In response to the problem of backwardness, Protestant missionaries and Chinese reforming nationalists educated Chinese girls and women to be better wives and mothers. For women missionaries, education was tied to the vision of "saving women and children through improving the homes."11 For late Qing and early twentieth-century Chinese reformers, families seemed a natural target for change because they believed a well-ordered family was the cornerstone of a strong state. Families should be better organised and managed, and improving mothers and wives as the inhabitants of those spaces became particularly important. ${ }^{12}$ In the early decades of the twentieth century, reformers of all stripes argued that women should be prepared to keep house with an eye toward such ideas as child psychology, nutrition and hygiene. ${ }^{13}$ Protestant missionaries had the same vision. "In the Protestant version of the emerging nationalist discourse, the domestic role of women was linked not just to the future of the church, but also to the fate of the nation." ${ }^{14}$ Education should enable women to excel in managing their homes and families.

Protestant missionary views on the need to improve Chinese domesticity were amplified by the growing importance of the social gospel in China. "The Social Gospel advocated responsible citizenship, clean government and greater government involvement in promoting social welfare and labour rights. And, crucially, it proclaimed democracy essential to Christian practice." ${ }^{15}$ Christian service organisations, such as the Young Men's Christian Association (YMCA) and newly founded Christian colleges followed the social gospel and sought practical ways to improve and save China by providing educational, medical and social services. ${ }^{16}$ "Service" was a way of illustrating Christian faith, and many hoped it would attract Chinese to Christianity. Social service also became a vehicle for conveying ideas about family practices and scientific-based

11 Barbara Reeves-Ellington, Kathryn Kish Sklar and Connie A. Shemo, "Introduction," Competing Kingdoms: Women, Mission, Nation, and the American Protestant Empire, 1812-1960, Durham, NC: Duke University Press, 2010, pp. 1-16.

12 Susan Glosser, Chinese Visions of Family and State, Berkeley: University of California Press, 2003; Joan Judge, Precious Raft of History: The Past, the West, and the Woman Question in China, Palo Alto, CA: Stanford University Press, 2008, pp. 115-16.

13 Helen M. Schneider, Keeping the Nation's House: Domestic Management and the Making of Modern China, Vancouver: University of British Columbia Press, 2011.

14 Dunch, "“Mothers to our country,"” p. 325.

15 Susan M. Rigdon, “Communism or the kingdom: 'saving' China, 1924-1949," Social Sciences and Missions 22 (2009): 168-213, p. 169.

16 Jun Xing, "The American social gospel and the Chinese YMCA," Journal of American-East Asian Relations 5(3-4) (1996): 277-304; Jeff Kyong-McClain, "Making Chengdu 'the Kingdom of God as Jesus conceived it': the urban work of West China Union University's Sociology Department," Social Sciences and Missions 23 (2010): 162-86. 
improvement of the home. In promoting Christian service to help China, the assumption was that foreign knowledge was superior. It should be considered an aspect of what Ryan Dunch has called "missionary paternalism." ${ }^{17}$ Women at Ginling College embraced foreign ideas about service to China, and with their foreign knowledge they claimed they understood the "needs" of China and could help solve China's problems by transforming backward family practices.

In the process, Ginling women localised aspects of modernity that were circulating globally in the first decades of the twentieth century. One aspect of the global modern was the standardisation of domestic practices through the field of home economics (or domestic science) which many Protestant missionaries taught as a new field of knowledge for transforming local societies. ${ }^{18}$ As Ellen Fleishmann has argued, home economics was simultaneously recognised in many parts of the globe among modernising elites as a way to "eradicate backward tradition." 19 She writes, "Educators, politicians, and social reformers everywhere were championing similar values (the importance of the well-regulated, clean, modern and moral home); and teaching similar subjects and skills (hygiene and sanitation, cooking, sewing, decorating, household budgeting, time management)." ${ }^{20}$ Social reformers in China were no exception.

Missionary teachers and social service organisations like the YMCA filtered ideas about social reform and domestic improvement to China as they served as agents of what Ryan Dunch has called "global modernity."21 Steps were taken to combine ideals of service, national strengthening and improving Chinese homes and families through social service. At Ginling, this work started out as missionary-directed efforts to improve the lives of Ginling's neighbours. As they established rural service stations in the late 1930s, educated Chinese women at Ginling became effective bearers of global concepts of childrearing, nutrition and other family practices. They, rather than their missionary teachers, motivated efforts to eliminate what they saw as intolerable Chinese backwardness.

\footnotetext{
17 Dunch, "Beyond cultural imperialism," p. 310.

18 Some examples include, Ellen Fleishmann, "Lost in translation: home economics and the Sidon Girls' School of Lebanon, ca. 1924-1932," Social Sciences and Missions 23 (2010): 32-62; Deborah Gaitskell, "Housewives, maids, or mothers: some contradictions of domesticity for Christian women in Johannesburg, 1903-39," Journal of African History 24 (1983): 241-56; Nancy Rose Hunt, “Domesticity and colonialism in Belgian Africa: Usumbura's Foyer Social, 1946-1960," Signs 15(3) (1990): 447-74; excerpts from Karen T. Hansen, "Introduction: domesticity in Africa," in African Encounters with Domesticity, ed. Hansen, New Brunswick, NJ: Rutgers University Press, 1992, pp. 1-36; Hyaeweol Choi, “'Wise mother, good wife': a transcultural discursive construct in modern Korea," Journal of Korean Studies 14(1) (Fall 2000): 1-34; Hyaeweol Choi, Gender and Mission Encounters in Korea: New Women, Old Ways, Berkeley and Los Angeles: University of California Press, 2009; and Michael Schneider, "Globalization and historical writing: home economics as internationalism in Japan 1920-1940," Waseda Journal of Asian Studies 23 (December 2001): 79-101.

19 Ellen Fleishmann, "At home in the world: globalizing domesticity through home economics in the interwar years," in Transnational and Historical Perspectives on Global Health, Welfare and Humanitarianism, ed. Ellen Fleischmann, Sonya Grypma, Michael Marten and Inger Marie Okkenhaug, Kristiansand, Norway: Portal Books, 2013, pp. 160-83, p. 175.

20 Fleischmann, "At home in the world," pp. 182-83.

21 Ryan Dunch, "Beyond cultural imperialism," p. 318.
} 


\section{The expansion of social service and domestic improvement projects}

At the beginning of the twentieth century, Chinese nationalists and Protestant missionaries were in general agreement that female education needed to stress domesticity, or better household management. Educators believed in the transformative power of home economics because it stressed the ways scientific and practical approaches might come to bear on managing the home. ${ }^{22}$ It was seen as a field that would prepare women for service - to their families and to the Chinese people. Chinese educators encouraged the development of domestic training in the Chinese-founded normal schools for girls that opened in the first years of the twentieth century.

In the second decade of the twentieth century, American home economics experts travelled to China to spread the word about the applicability of the field in China's relatively new institutions of higher learning. In 1922, two female home economics experts from Columbia Teachers College, including the Head of the Department of Household Administration, visited several Christian colleges "to discuss the advisability of extending the work of home economics." ${ }^{23}$ At almost the same moment, two professional home economists from Oregon State College, Ava Milam and Camilla Mills, travelled to China with the support of the Women's Foreign Mission Board of the Methodist Church. ${ }^{24}$ Their goal was to establish a department of home economics at the missionary-founded Yenching University (Yanjing daxue) in Beijing. ${ }^{25}$ They were successful, and in 1923 female students started to take classes in Yenching's department of home economics.

Milam's efforts to spread the gospel of home economics were based on a belief that the field had a universal power to benefit societies but that it had to be localised to fit new environments. "If the study of home economics could contribute to the improvement of home life and society in one country, it could do likewise in other countries." 26 This was not to be wholesale adoption of American-style home economics however. In the case of China, Milam believed that Westerners could "open the way," but the field had to be a cooperative endeavour between Chinese and Americans. "The great differences of economic

\footnotetext{
22 Schneider, Keeping the Nation's House, pp. 12-15.

23 Elizabeth Pepys, "Scientific housekeeping," North China Herald (8 April 1922), p. 138.

24 Helen Schneider, "The professionalization of Chinese domesticity: Ava B. Milam and home economics at Yenching University," in China's Christian Colleges: Cross-Cultural Connections, 1900-1950, ed. Daniel H. Bays and Ellen Widmer, Palo Alto, CA: Stanford University Press, 2009, pp. 125-46.

25 For Yenching's history, see Philip West, Yenching University and Sino-Western Relations, 1916-1952, Cambridge, MA: Harvard University Press, 1972; Arthur Lewis Rosenbaum, "Yenching University and SinoAmerican Interactions, 1919-1952," The Journal of American-East Asian Relations 14 (2007): 11-60. 26 Ava Milam Clark and J. Kenneth Mumford, Adventures of a Home Economist, Corvallis: Oregon State University Press, 1969, p. 140.
} 
levels and the differences in customs in family life between China and the United States made us realize that the building of these courses must be done with the aid and approval of the Chinese if home economics courses were to become indigenous." 27 Her goal was to train Chinese women in theories and scientific principles of home economics. Concepts, once grasped, would be turned into practical solutions by a cohort of Chinese experts. To train those experts, Milam developed fellowship opportunities for women to study home economics in the United States and provided ongoing advice to leaders of institutions as they expanded their home economics programs. ${ }^{28}$ Milam's venture to expand home economics was taken up by a generation of Chinese educators. Many colleges and universities - Christian and national - established departments of home economics over the course of the 1920s to the 1940s. ${ }^{29}$ Graduates worked in fields including nutritional science, child welfare, education and social work, using home economics knowledge to better the lives of Chinese people.

Home economics as developed in the United States had much in common with the field of social work. Both fields aimed to apply scientific methods to the problems of the human condition. Both disciplines connected to the development of social sciences in the West. ${ }^{30}$ Like home economics, social work required investigation of a set of circumstances and the application of practical means for improvement. Sociology appealed to Chinese and Westerners alike who adhered to the social gospel vision of Christianity because both, social gospel theology and sociology, shared ideas of reform and improvement. ${ }^{31}$ Like home economics, training in the fields of sociology and social work started in missionary-founded schools. One of the first departments of sociology opened at Yenching in 1922, and it trained both women and men for social service. ${ }^{32}$ Other missionary-founded colleges had similar departments, including Ginling College where sociology became one of the most popular majors. ${ }^{33}$

\footnotetext{
27 Ibid., p. 159.

28 Ibid., pp. 185-201. Milam pushed for the development of home economics in other parts of Asia as well. On the significance of Ava Milam in the context of home economics in Korea, see Choi, "“Wise mother, good wife,"' p. 15.

29 Schneider, Keeping the Nation's House.

30 Yung-Chen Chiang, Social Engineering and the Social Sciences in China, 1919-1949, Cambridge: Cambridge University Press, 2001. See particularly the introduction.

31 Jeff Kyong-McClain, "Making Chengdu 'The kingdom of God as Jesus conceived it."

32 Dong Tianmin, 董天民, “Yanda shehuixue xi jianshi" 燕大社会学系简史 (A Brief History of the Sociology Department), in Bing Xin, Xiao Qian et al., Yanjing wenshi ziliao, di ba ji (燕京大学文史资料, 第八辑), Beijing daxue chuban she, 1994, pp. 65-69. On their social work activities in the early 1930s, see, Wang Jiachen, "Yanjing daxue, shehui xuejie danxingben," Yenching University, Volume on Sociologists, August, 1936, SHAC RG 113/291.

33 “Biye tongxue xiaoxi" 毕业同学消息 (News about our graduates), Jinling nüzi wenli xueyuan xiaokan (Ginling College for Women Review) 115 (5 May 1944).
} 
One organisation where Ginling women served after graduation was the Young Women's Christian Association (YWCA). ${ }^{34}$ The Chinese YWCA and YMCA were both involved in projects to improve the homes of China. For example, in 1923 the Shanghai YWCA carried out "House-warming" activities. "Among the aims of the Association has been the teaching of the proper care for babies, baby welfare, home hygiene, home economics, and home ideals." To further those aims, they held "playground work on Saturday morning for 70 children of the neighbourhood who must come with clean hands and face or else they will not be admitted." ${ }^{35}$ In 1928, the Hangzhou YMCA and YWCA jointly sponsored work on domestic improvement, which included a contest for better babies and a health movement. ${ }^{36}$

Ginling students conducted similar activities to transform the lives of their neighbours in Nanjing. In the 1940s, former College president Mrs. Lawrence Thurston explained there were "six main avenues of service" at pre-war Ginling. Teachers encouraged students to conduct practical service that included extension courses; child welfare day school; a homecraft extension course that provided looms for women to start their own businesses; evangelical work at neighbourhood centres; medical centres with trained nurses; and provided a loan fund for women (perhaps similar to modern day microloans). ${ }^{37}$ Much work was realised under the guidance of Minnie Vautrin, who was known for her work with "neighborhood education, homecraft-industrial education, and experimental secondary education." ${ }^{38}$ In 1924, when they realised neighbourhood children did not attend school, Ginling students, under the guidance of Vautrin, started teaching children to read in a so-called "Practice School." Vautrin wrote, "Last year there were fifty little boys and girls studying there-learning to work, learning to play, learning those things which make life richer and better. Each Sunday afternoon there is a very modern little Sunday School there, conducted by a group of Ginling students." ${ }^{\prime 39}$ In the 1930s, Vautrin described how students worked to improve public health by distributing mosquito nets to prevent the spread of malaria and offered quinine to prevent malaria from recurring. ${ }^{40}$

\footnotetext{
34 On the YWCA see Elizabeth A. Littell Lamb, "Going public: the YWCA, "'new" women and social feminism in republican China," Ph.D. diss., Carnegie Mellon University, 2002.

35 "Practical work organized by the Chinese Y.W.C.A.," North China Herald (1 December 1923): 648.

36 Gui Dehua 桂德华, (photographer), “Ertong weisheng yundong, Baby's Health Exhibit” Liangyou (The Young Companion 良友) 33 (December 1928): 38.

37 "Ginling in Nanking: an interview with Mrs. Lawrence Thurston," China Christian Advocate (February 1941): 3.

38 Ellen Widmer, “The seven sisters and China, 1900-1950," in China's Christian Colleges: Cross-Cultural Connections, 1900-1950, ed. Daniel H. Bays and Ellen Widmer, Palo Alto, CA: Stanford University Press, 2009, pp. 83-101, p. 91.

39 Minnie Vautrin, "How Ginling students are sharing with their neighbors," n.d., UTS, MCT Papers, box 8 , folder 27 .

40 Minnie Vautrin, “The mosquito campaign," 1930-1931, UTS, MCT Papers, box 8, folder 31.
} 
Vautrin was not alone in these activities. In the mid-1930s, Mareb Mossman, a sociologist teaching at Ginling, started a community centre on campus and did group work for children. ${ }^{41}$

Ginling students and faculty followed the social gospel in attempts to find lasting solutions to the social problems they saw in Nanjing. For example, Ginling student and future YWCA secretary, Deng Wuzhi, reported that a sociology class visited a centre for poor children. After their visit they presented a series of recommendations which included asking the government for further support, suggesting improvement of sanitation, and requesting better record keeping and statistics about the care of the children. ${ }^{42}$ Deng, a Christian, feminist, and communist who became a proponent of better workers' rights as leader of the YWCA, learned some of her practical ideas about service at Ginling. She was encouraged to major in sociology by teacher Mary Treudley, who was "known for her philosophy of relating religious education to contemporary social problems." ${ }^{43}$ Deng's and her classmate's efforts to permanently improve the quality of life for Chinese people show how they understood ideas of service as learned from their missionary teachers.

In the pre-war period, the social service work directed by Christian Colleges and the YMCA/YWCA movements took place in urban areas. But before 1927, when no central government alleviated the burden of economic and natural disaster carried by the peasant, and when the newly formed Communist party was concerned with the urban proletariat, missionaries and pastors were working among the rural masses. Early efforts to combine social service with agricultural education were made at a few Christian colleges and by some Chinese leaders, like James Yen Yan Yangchu and his rural reconstruction experiment at Dingxian.

Work with the rural populations on Christian reform projects became more widespread in the late 1920s and the 1930s. At that point, many efforts to transform Chinese society through social service were led by Chinese Christians. One reason for this was the changed political landscape after 1927, when Chiang Kaishek established a Nationalist government in Nanjing and took steps to exterminate the Communists. In this new environment, the Nationalists mandated that the heads of Christian schools had to be Chinese, religious lessons must be elective, and that students receive patriotic instruction. ${ }^{44}$ It was after

\footnotetext{
41 Wang, Ying'an, "Yangwu gaicheng de ertong fuli shiyan suo" (From a sheep shed into a child welfare station), in Yongjiu de sinian (Memory Forever) 永久的思念, ed. Jinnüda xiaoyouhui (Ginling Women's College Alumnae Association), Nanjing: no publisher information available, ca. 1993, pp. 111-13.

42 Deng Yu-dji, "The Ping Erh Yuen," Ginling College Magazine 2(1) (December 1925): 31-37.

43 Emily Honig, "Christianity, feminism, and communism: the life and times of Deng Yuzhi," in Christianity in China: from the Eighteenth Century to the Present, ed. Daniel Bays, Palo Alto, CA: Stanford University Press, 1996, pp. 243-62, p. 252.

44 Daniel Bays, A New History of Christianity in China, Chicester, West Sussex and Malden, MA: WileyBlackwell, 2012, p. 125.
} 
the promulgation of these regulations that $\mathrm{Wu}$ became head of Ginling. Despite the anti-Christian tone of the new rules, the change in leadership revitalised the spirit of reform for many Christians, both Chinese and foreign. This is partly because Chiang's new wife, Song Meiling, was from a prominent Christian family and Chiang himself converted. ${ }^{45}$ Many Christian service organisations believed there was a possibility of working with the government on important projects of reform.

In the 1930s, Christians became more involved in rural service and reform projects. In 1929, the Chinese-led National Christian Council (NCC), which had adopted many tenets of the social gospel, created the position of secretary for rural life to Christianise rural populations. ${ }^{46}$ The Council was, like many other Christian groups, interested in the improvement of Chinese homes. "The NCC had a special work division devoted to 'Christianising the home,' among whose goals were raising the status of women and children in the home, introducing village women to domestic 'science' and encouraging them to take a more active role in the education of their children and promoting public health." ${ }^{47}$ After 1934, Chiang Kaishek and his wife appealed to Christian missionaries to plan rural restoration projects in areas that had been cleared of Communist bases. Rural social service became an important goal that aligned Nationalist government and Christian interests.

The project of "reconstruction" in the wake of victory over Communists fed into a broader Guomindang project of revitalisation. The Guomindang and missionary advisors designed the New Life Movement to create a more disciplined population in preparation for what many saw as a coming war with Japan. It emphasised frugality, personal hygiene, cleanliness and orderliness and therefore also touched on family habits and the improvement of Chinese women. ${ }^{48}$ Song Meiling, as one of the leaders of the movement, called on educated women to aid in its organisation. She emphasised the importance of social service in ways similar to those expressed by Christians in earlier years. ${ }^{49}$ The Guomindang and educated Chinese women, such as those at Ginling, were in agreement that educated women were most suited to attempt to change the practices of "backward" Chinese women.

\footnotetext{
45 Ibid., pp. 126-27.

46 Rigdon, "Communism or the kingdom," p. 181.

47 Ibid., p. 185.

48 Sue Groenwald, "New life, new faith, new nation, new women: competing models at the Door of Hope Mission in Shanghai," in Competing Kingdoms: Women, Mission, Nation, and the American Protestant Empire, 1812-1960, ed. Barbara Reeves-Ellington, Kathryn Kish Sklar and Connie A. Shemo, Durham, NC: Duke University Press, 2010, pp. 195-217, p. 195.

49 For more on the New Life Movement and family reform, see Helen M. Schneider, "Women and family education reform in wartime China, 1937-1945," Chinese Historical Review 20(2) (November 2013): 180-210.
} 
The Guomindang and the NCC efforts led to a growing interest in working in rural service and in improving the quality of women, but this did not immediately result in widespread service for rural women. In 1936, Ginling graduate Liu Yu-hsia wrote about her experiences in the YWCA. Even though she focused on developing work in rural China, Liu criticised the YWCA for being, "not too much conscious of the important place of rural women. I am sending you a poster... It reminds people that $85 \%$ of our women are rural." ${ }^{50}$ Liu's work convinced her of the need for college-trained women who were better prepared than junior-middle school girls to lead rural efforts.

Rural problems are so many and work especially with women so slow and indefinite, that it really requires girls with analytical minds and organizing power in order to have clear understanding of these situations and the right method of working. Then, usually in the country one is pretty well cut off from all intellectual and helpful resources like libraries, hospitals, teachers, and friends and easily come to the point of desperateness and discouragement. In order to prepare for that, I think a spirit of Christian service and will to develop oneself to be the best help in such a situation are important. ${ }^{51}$

Liu notes qualities that only a Christian college could instil in Chinese women. Ginling eventually provided training in rural service - three years after Liu wrote her letter.

\section{The expansion of rural social service in wartime}

Rural service work at Ginling, and at other institutions, developed in the late 1930s in great part due to the war against Japan. The war led the Nationalist state to ask more of its citizens and accelerated the desire of educated women to serve their country. One reason why Ginling expanded their social service was the promulgation of new government regulations. After the full-scale Japanese invasion in August, 1937, the Nationalist government, through its Ministry of Education, ordered colleges and universities to establish more social education projects which they believed would rationalise society, improve national morale and encourage participation in wartime efforts. ${ }^{52}$ From its wartime capital Chongqing, in Western China, the Nationalists partially funded these efforts even when the military was struggling against the Japanese. Wu was aware of

\footnotetext{
50 Liu Yu-hsia to Miss Greist, 24 October 1936, UBCHEA RG 11 box 138-2745.

51 Ibid. Liu continued this work at least until early 1938. See, Catherine Sutherland to Ginling, 18 March 1938, UBCHEA RG 11 box 138-2745.

52 Ou Tsuin-Chen, "Education in wartime China," in Nationalist China During the Sino-Japanese War, ed. Paul K.T. Sih, Hicksville NY: Exposition Press, 1977, pp. 89-123, p. 116.
} 
the Nationalists' policies. In 1939 she wrote, "The Minister of Education has sent notices to all the schools and colleges for them to promote 'Social Education' which includes adult education, and other forms of extension in the work for the community in which the institution is located." 53 Throughout her career at Ginling, Wu had encouraged her students to work in social service. ${ }^{54}$ The new rules did push her to expand these efforts, but most importantly for $\mathrm{Wu}$, "social education" was a "field of service which a Christian women's college ought to be doing seriously." 55

Another reason for the expansion of social service had to do with the physical relocation of the College. Ginling was one of the many colleges on the east coast in the path of the 1937 Japanese invasion and had to abandon their Nanjing campus. Ginling administrators accepted the offer of the West China Union University to join them on their campus in Chengdu, Sichuan. As many faculty and students travelled westward they learned about their country. One student wrote about the trip, which took two months, "This is the first time I have ever really traveled in China. I am surprised at the richness of the country and this makes me hope." 56 They also saw more of the poverty and hardship of the population with which they had not previously been acquainted.

After Ginling was established in Chengdu, they continued to serve their nearby neighbours much as they had in Nanjing. During the academic year 1939-1940, students and faculty planned and carried out social education programs like literacy training (mostly for women and children, but also for workers); citizen's education that included lectures, showing movies and opening a reading room; health education which provided public health guidance, pre- and post-natal counselling for mothers, and a playground for children; production education to disseminate ideas about better weaving, embroidery and handicraft production; and War of Resistance education in which they lectured on the wartime situation, conducted interviews with soldiers' families and tried to help them, propagandised during school breaks, and instilled knowledge about air defence and anti-poison gas defence. ${ }^{57}$ The Ministry of Education did monitor and support their efforts. One wartime inspection reported that the school was carrying out the "correct kind of social service," which included encouraging sewing and weaving items for soldiers at the front. ${ }^{58}$

\footnotetext{
53 Wu Yifang to Mereb Mossman, 15 November 1939, UBCHEA RG 11 box 139-2786.

54 Waelchli, "Wu Yifang: abundant life in training women for service," p. 159.

55 Wu Yifang to Mereb Mossman, 15 November 1939.

56 Wei Djen-dze “Trip to Hankow," 15 July 1938, UTS, MCT Papers, box 7, Folder 4.

57 "Minguo ershiba niandu Jinling jieban shehui jiaoyu gongzuo jihua dagang" (Draft of 1939 Ginling social education work plan) SHAC RG 5/11512; Liu Shuyuan, "Ben xueqi lian ban shehui jiaoyu gongzuo" (Social education work from this semester) Jinling nüzi wenli xueyuan xiaokan (Ginling Women's College Review) 70 (January 20, 1940): 5-6.

58 Xu Songming (俆诵明) “Shicha sili Jinling nüzi wenli xueyuan baogao" (Report on visit to Private Ginling College for Women), SHAC RG 5/1997.
} 


\section{Preparation for rural service}

After they relocated to Chengdu, Ginling soon started planning for rural service. The wartime disruption and relocation to Sichuan was part of the reason, as was the growing importance of rural work for China's Christians over the course of the 1930s. As chair of the National Christian Council in the late 1930s, Wu was undoubtedly aware of the trends in rural service, but she wanted women's issues to be addressed. Her determination to accomplish this can be seen in the letters exchanged between Wu and Mereb Mossman, who had taught sociology and led social service at Ginling in the early 1930s. In November 1939, Wu wrote, "the fact is, there is a real lack of women well-trained academically and technically and with a real spirit of service." ${ }^{59}$ Wu's great concern was that women should conduct service that male leaders were ill-prepared, or disinclined, to carry out. For example, in January $1940 \mathrm{Wu}$ wrote to Mossman about the efforts of Chinese progressive educators under James Yen to establish a college of rural reconstruction. ${ }^{60}$ She worried that Ginling was not "training women workers for the rural families." She continued, "In a large institution the main emphasis is bound to be placed on the training of men workers along various lines including civil servants for the hsiens [counties]. When I first thought of setting up a rural station, I had in mind giving a short training course of two years to train women workers for the practical work in the country." ${ }^{61}$ Wu's concern for training Ginling women to be leaders, who would then pass leadership skills on to rural women, continued into the 1940s. In April Wu wrote to Mossman:

The need for well-trained women for rural work is urgent. We are too slow in taking up the challenge, and the men's institutions see the opportunities and go ahead with programs, even if they do not know how to carry them out. Quite often it weighs very heavy on my conscience whenever I realize that Ginling, as a woman's college, is not taking up the responsibility as she ought to in this war time, particularly in meeting definite fields of work for which college women should be trained. ${ }^{62}$

There is no small degree of competition here with male-led institutions. This is based on Wu's sense that educated women should be trained in specific areas where they could best serve China.

\footnotetext{
59 Wu Yifang to Mereb Mossman, 15 November 1939, UBCHEA RG 11 box 139-2786.

60 She is referring to Yen's efforts to found the Rural Research and Training Institute at Xiemachang, Sichuan, which was working in conjunction with the Nationalists' National Rural Reconstruction Institute at Beibei. The NCC started experimental rural centres in 1939. See Rigdon, “Communism or the kingdom," pp. 193-95. 61 Wu to Mereb Mossman, 20 January 1940, UBCHEA RG 11 box 139-2789.

62 Wu Yifang to Mereb Mossman, 1 April 1940, UBCHEA RG 11 box 139-2786.
} 
In most of her wartime letters to Mossman, Wu inserts a plea for Mossman to return to Ginling in order to train students in social work. But Mossman pushed back against the idea that she, as a foreign expert, was necessarily the best qualified to conduct this work. In a 1936 letter explaining why she could not return to China, Mossman wrote, "And there is the other question as to the whole future of Ginling and whether it is better that I or someone else (Chinese) should be the one to develop the social work training there." Through development of the field, she added, "Ginling is best suited to make a powerful contribution to China and Chinese life." ${ }^{63}$ Mossman believed there were Chinese qualified to serve in this capacity.

$\mathrm{Wu}$ was not adverse to hiring qualified Chinese, but being best qualified to serve meant having an academic and technical grasp of ideas about service from the West. Wu therefore encouraged Ginling graduates to study abroad, which usually meant taking a higher degree in the United States. In a late-war letter Wu asked Mossman where students should study rural sociology. Wu wrote, "I realize that rural conditions in America and here are so different that studies in America cannot help in the practical work." However, students could "get at the fundamental principles and the applications according to conditions there" and then apply that knowledge to China-specific situations once returned. ${ }^{64}$ The foreign training of Chinese women was an important way that ideas about service became localised. Once they were trained in "fundamental principles," $\mathrm{Wu}$ wooed them back to Ginling to serve in ways practical for China.

Wu's efforts to train social service leaders were augmented by Ginling's establishment of the Department of Home Economics. The department started offering courses in the fall of $1939 .{ }^{65}$ Of particular interest was the field's possibility of providing expertise in areas of child welfare and nutrition. Like rural sociology, Wu imagined American home economics might provide a base of knowledge on which Ginling graduate women could work out the practical applications of the field for China. Wu went to great lengths to cultivate talent in both fields. In the case of one student, she suggested topics of research that would best help China-and Ginling College. In $1943 \mathrm{Wu}$ wrote a series of letters to Li Meiyun who was studying home economics at Cornell University. In one, $\mathrm{Wu}$ asked $\mathrm{Li}$ to consider changing her dissertation topic.

I wonder if you might not think of some subject in the field of rural education but related to home economics.... While you are studying here you want to fit that study into the needs in China. Rural reconstruction is becoming a more important phase of the large program

63 Mareb Mossman to Rebecca Greist, 22 May 1936, UBCHEA RG 11 box 139-2786.

64 Wu Yifang to Mereb Mossman, 5 January 1945, UBCHEA RG 11 box 137-2757.

65 Jinnüda dashiji, 1913-1953 (A Chronology of Ginling Women's College, 1913-1953), 1993, p. 17. 
of reconstruction in China. Furthermore, in our effort to set up a really democratic government, popular education for the masses in the rural regions is important. ${ }^{66}$

Wu's vision of service was to create better citizens and a better, more democratic China-ideas in keeping with the social gospel approach of many American missionaries to China just a few decades earlier.

Wu's efforts to expand the pool of Chinese women educated for service had some effect. In the case of Li Meiyun, Li researched social, economic and political factors in rural Sichuan and about how to improve education there ${ }^{67} \mathrm{Wu}$ asked Li to consider returning to Ginling after finishing her doctorate as a member of the rural service or home economics staff. To make her point, Wu explained the goals of rural work, the first of which was "to give direct service to the rural homes." Another aim was to prepare women workers for rural reconstruction who had "a spirit of Christian service." Those women, Wu continued, "will be increasingly needed in view of the important rural reconstruction and the attention our Government is giving to developing this program." Wu also explained how Li's training would be most useful. "In fact, there can be much correlation and cooperation between the home economics and a rural service station. For instance, such problems as nutrition, clothing and toys for the children in the rural places can be worked out under the direction of the professors." ${ }^{68} \mathrm{Wu}$ was not able to convince Li to join Ginling's rural staff$\mathrm{Li}$ went to the University of Nanking. Nonetheless, her interactions with Li show how Wu consistently pushed for the growth of home economics and rural service to improve Chinese family life.

\section{Ginling's wartime rural service stations}

Wu had asked Li Meiyun to return to a rural service station that Ginling had started earlier in the war. The College opened their first rural service centre in Sichuan at Renshou (Jenshow) in the fall of 1939. The centre remained open until March 1943. ${ }^{69}$ Ginling chose Renshou in part because a Canadian mission station was there and the Nanking University Agricultural College was expanding work in that area. ${ }^{70}$ In the last two years of the war, they operated a

\footnotetext{
66 Wu to Miss Mei-yun Li, 9 July 1943, UBCHEA RG 11 box 138-2769.

67 Mei-yun Li, "An analysis of social, economic, and political conditions in Peng-Shan Hsien, Szechwan China, looking toward improvement of educational program," Ph.D. dissertation, Cornell University, 1945.

68 Wu Yifang to Miss Li, 28 November 1943, UBCHEA RG 11 box 138-2769.

69 Jinnüda dashiji, 1913-1953, 1993, pp. 17 and 23. In Chinese it is “Renshou" (仁寿县) but in the English language documents it is often "Jenshow."

70 Thurston and Chester, Ginling College, p. 116; Irma Highbaugh, "Ginling College begins a rural service station in Szechuan," The Chinese Recorder 70 (March 1940): 144-49.
} 
station at Zhonghechang. In both locations the goal of the work was primarily to serve the rural families of China and to train a cohort of women qualified to do so.

In the spring of 1939, Ginling sent two women, Phoebe Hoh and Wu Suen-i, to Renshou County to study the feasibility of starting a rural service centre. Hoh did her preparatory work four miles south of Renshou at Chen Chia Tze (she translated it "Chen's Ancestral Home"). She discovered villagers travelled to the market town of Renshou once or twice a week, usually on foot. Because villagers saw their trip to market as a business and social occasion, Hoh believed it would be just the place for Ginling to establish a "social centre." There villagers from all directions could rest, chat and be entertained. Hoh wrote, "After friendships have been established, a regular program of religious education, health, singing, lecturing on all sorts of topics can be carried on." ${ }^{71}$ When the visitors returned to their home villages, they would tell others what they had learned.

Hoh suggested ways that Renshou might begin to solve the problems of rural backwardness. The content of instruction could be based on her observations of villagers' lifestyles, "from our talks with the people we have been told many interesting things about the cooking of food, washing of clothes, working in the field, spinning and weaving. We noticed that we could suggest many ways in which the work might be carried on with greater economy of time and energy." In addition to improvement in domestic work, Hoh believed they could raise education standards. She noted that many villagers had learned some characters, but forgot them because they did not read enough. "The habits of the people are not yet cultivated. The never-ending hard work, the impoverished living, the stupefied spirit leave no time, no heart, no taste or desire for reading."72 Hoh's goals were to adapt kinds of social service work similar to what Ginling had been doing in Nanjing (literacy, playgrounds for children, domestic advice, medical examinations, handicraft production) to the rural scene.

In addition to helping raise the standards of rural life, another goal in the development of Renshou was to train more Chinese women to develop rural work on their own. Wu wrote to Mereb Mossman about this problem and the work at Renshou in 1939. "Last spring, when Miss Phoebe Hoh and Wu Suen-i went down to make a start, it did not go very well, but a foundation was made in making contacts with local people. This autumn we are very happy that the Women's Foreign Missionary Society (W.F.M.S.) loaned us Irma Highbaugh for a period of two years." ${ }^{17}$ It is clear that Wu believed some foreign expertise was still needed in order to make Renshou a success.

71 Phoebe Hoh, “November days at Chen Chia Tze," November 1939, UBCHEA RG 11 box 137-2756.

72 Ibid.

73 Wu Yifang to Mereb Mossman, 15 November 1939, UBCHEA RG 11 box 193-2786. W.F.M.S. was affiliated with the Methodist Episcopal Church. 
Irma Highbaugh, who Wu was so pleased to have join Renshou's staff, shared Wu's vision of training personnel. She included it on her list of rural service goals.

1. To serve the rural people and meet their needs. It is this that governs all policies.

2. To provide a center where the college students can get practice, inspiration and vision for their rural work.

3. To produce materials out of actual rural experiences and research which shall eventually go into the rural reconstruction curriculum of the college. ${ }^{74}$

Training was important, but Highbaugh prioritised the meeting of Chinese "needs" as the first purpose of their work. Rural service centres become a place for women to expand their horizons for service, at the same time emphasising the development and betterment of Chinese life practices as the educated women saw fit.

The idea of "meeting the needs" of the Chinese people and making a difference in their lives was discussed by Ginling workers. In a later account, Xiao Dingying (Sociology 1939) explained that their work at Renshow focused particularly on maternal and child health, education and production. The maternal and child health division ran health clinics and provided vaccinations for young children, a service that was free for the poorest clients. The handicraft division encouraged cross-stitch handiwork, where local women decorated bedding and tablecloths. Ginling College then facilitated their sale abroad to get foreign currency. ${ }^{75}$ An additional element, not remembered in the later account, is emphasised in contemporary accounts, is the "need" to modernise family practices in rural homes. Hoh made this clear in her assessment of Chen Chia Tze. Ginling students worked on what Highbaugh called "family life training," in part by creating nursery age play groups, which, she explained, gave children routines as an important part of their development. Children learned "proper play" (with toys), how to use the toilet, and received more nutrition. ${ }^{76}$

Two anonymous reports about Renshou, written in the early 1940s, echo the ideas of training workers, establish the need for changing family practices, and explain the ways Renshou served China by meeting the country's needs. The first report, "A Plan for Work in a College-Sponsored Rural Service

74 Highbaugh, “Ginling College begins a rural service station," p. 145.

75 Xiao Dingying 肖鼎瑛, “Renshou xian xiangcun fuwu chu” (Renshou county rural service station) 仁寿县乡村服务处, in Yongjiu de sinian (Memory Forever) 永久的思念, ed. Jinnüda xiaoyouhui (Ginling Women's College Alumnae Association), Nanjing: no publisher information available, 1993, pp. 109-10.

76 Highbaugh, "Ginling College begins a rural service station," p. 146. 
Station," notes a goal was to train physically strong rural leaders who would eliminate "deadening customs" and who would work for "their own economic improvement at the same time that they unselfishly take responsibility for the uplift of their community." 77 The second report continues in this vein:

The Rural Staff feel that the needs of the rural women and children are economic with need for small home industries; health needs - common hygiene practices and especially maternity welfare, need to learn food values and the way to adequately nourish the family; need to change the arrangement of homes for better and happier use of the family; and for children there is a need for better clothing and toys. ${ }^{78}$

The authors of these documents make clear value judgments about the superiority of their vision of progress in rural areas. The first report is specific about the shortcomings of rural people. "Cheating, whether it be in embroidery work or as a teacher cheating on her time invested, are moral problems." It also reported, "Superstition and customs that mar and dwarf personality are religious problems and can be solved no other way." ${ }^{\prime 79}$ The report does not state outright any evangelical aims, but instead suggests specific social programs to guide the development and reform of the population.

Ginling rural service workers thought very carefully about how to overcome the cultural, moral, and religious shortcomings they encountered in Renshou. Changing "dwarfed personalities" began with the education of children. One report echoed Highbaugh's observation of the need for better home environments. It suggested "family life work," the objectives of which was "to change family life producing a clean, light, airy home in which a child may grow and change parents to realise the basic needs of the developing personality of the little child." They started a "preparation for marriage class" for sixth grade boys and girls of the Canadian Mission's Hua Ying School to involve children and their parents in the "project of changing the home." They worked in conjunction with Hua Ying and the local government school to establish a girls' club where girls learned how to express themselves, "how to be a person," how to fit in with their environment, and how to be leaders. ${ }^{80}$

The Ginling workers also tackled the issue of morality by dealing with women's customs. The report noted, "Idle life among the leisure class of Jenshow is just one long summer of gambling." Ginling organised a women's club to encourage more patriotic activities and social work among the women. "The women

77 "A plan for work in a college-sponsored rural service station," typescript, English, no author, ca. 1941, SHAC RG 668/12.

78 “Renshou, Sichuan Province," January, 1941, typescript, English, SHAC RG 668/12.

79 "A plan for work in a college-sponsored rural service station."

80 Ibid. 
responded by raising money and giving thirty wadded jackets to the old people in the Old People's Home. They want to be organized and carry on some more serious work." ${ }^{\prime 1}$ The aim here was to change habits of service among another cohort of women.

Ginling Renshou workers tried to reform rural families by using exhibitions and displays. They designed an exhibit in six rooms of the service station, with one room each devoted to "embroidery, health, foods and nutrition, model house, toys, children's clothing, and poultry." The food display included an exhibit of rabbits, some of which had eaten carrots and some of which had not. The report noted that of the exhibit attendees, "many sighed and said: we did not know that carrots were so good a food and so we fed ours to the pigs." ${ }^{12}$ One report claimed that the home exhibit "gave new ideas on family life to thousands of people during the winter vacation of 1940 and 1941." 83

The authors of both reports felt that much more could be done. One report recommended that Renshou staff be augmented by a trained home economist to "work on Family Life Improvement." It suggested that the local schools teach "home-making", and "that a wholesale campaign be pursued to eliminate one evil in the home equipment such as changing the toilets or covering food." ${ }^{84}$ Cleanliness was important from a public health standpoint, but also inched the rural people closer to a moral and spiritual transformation.

Students found the work difficult, but a good learning experience. They discovered local people were "not conservative as they had always thought, but wide awake and very receptive to new ideas." The report added, "At the same time [we] felt there was great need of long consecutive work to accomplish lasting results." ${ }^{\prime 5}$ Experience and observation empowered students to make recommendations for longer term change. One wrote, "There is a lack of money and method. Money could be loaned by cooperative banks. Methods could be supplied by spinning machines with thirty spindles, which are locally made and can be purchased for thirty dollars." ${ }^{16}$ While the centre did receive some foreign aid and government support, finances were stretched thin as the war with Japan continued.

Despite the call for "long consecutive" work, Ginling could not maintain Renshou. The College moved the rural service station to Zhonghechang (Chung

81 Ibid.

82 "Renshou, Sichuan Province."

83 "A plan for work in a college-sponsored rural service station."

84 Ibid.

85 "Renshou, Sichuan Province."

86 "Ginling in Chengdu—-summer service at Jenshow," n.d., UTS, MCT Papers, box 7, Folder 4. 
Ho Chang). ${ }^{87}$ Zhonghechang was advantageous because, unlike Renshou, it was proximate to Ginling's Chengdu campus, and like Renshou, it was the site of a Canadian mission station and it received some government and foreign funding. The stations were similar in terms of stated goals, including training women leaders for social service. Practical service work at rural stations complemented book reading and classroom instruction. For example, soon after Zhonghechang opened, the home economics staff offered a number of classes on family relations and children's welfare (nutrition and psychology) in conjunction with the department of sociology. ${ }^{88}$

As with Renshou, Zhonghechang workers strove to improve the conditions (or "respond to the needs") of rural populations, particularly women and children. This is emphasised at several points by Ginling 1941 sociology graduate Anna Hsiung (Xiong Yana) who was closely involved in Zhonghechang and in Ginling's post-war rural service work. Hsiung, as the daughter of a Methodist church superintendant and a graduate of a Christian high school, felt the need for Christian service and social improvement. ${ }^{89}$ In 1944 she wrote that the goals of Zhonghechang's rural nursery school were to lessen the burdens for peasant women, to train child welfare workers, to experiment with possible techniques for nursery schools in the countryside, and to develop good citizens. ${ }^{90}$ She expressed the needs she saw in a typescript, writing, "If China is to become a real democratic country, women, half of her population, must not be neglected. We felt deeply that to educate the rural women was one of our unalienable obligations. Therefore, a women's class was organised as an experiment aimed at training women for democracy." ${ }^{\prime 11}$ Hsiung aligned the goals of Christian service, a feminist agenda of an aware population, and the creation of a strengthened national polity.

In a pamphlet published by the Association of Universalist Women, who helped sponsor Ginling work at Zhonghechang, Hsiung and her colleague Tsu Yu-dji wrote most extensively about their work for children. They reported holding twice-monthly parents' meetings to encourage projects to benefit children. These projects were similar to those at Renshou in terms of cleaning and covering toilets for small children's use, making more comfortable clothing, creating toys for the children and improving children's nutrition. Hsiung and Tsu wrote that their child welfare efforts, supported in part by the Sichuan

87 Known as Chung Ho Chang in English language materials, it was at Zhonghechang in Huayang County 中和场, 华阳县.

88 Jinnüda da shiji, p. 24.

89 Hsiung Ya-na, letter to Mrs. Mills, 9 July 1947, UBCHEA RG 11 box 137-2757.

90 Xiong Yana 熊亚拿, “Sichuan sheng zhengfu shehui chu, Jinling nüzi wenli xueyuan he ban xiangcun tuoersuo" (Sichuan provincial social bureau and Ginling Women's College jointly operated rural nursery school), Jinling nüzi wenli xueyuan xiaokan (Ginling Women's College Review) 112 (16 March 1944) (report is from the fall of 1943), pp. 3-4.

91 Hsiung Ya-na, “Our first year at Chung Ho Chang," July 1943-1944, UTS, MCT Papers, box 10, folder 14. 
Social Bureau, "seem fitted to the Chinese rural life." The Bureau was impressed enough to ask them to participate in provincial-level child welfare exhibitions. Ginling workers trained women to work in village nurseries, using the facilities of another cooperating unit, the United Church of Canada for the training. As a result, "The 'Bible woman' of the church has a good chance to tell the Bible stories and to introduce Christianity to the girls and women who are attached to our project." 92 Here job training came with a dose of evangelism.

The work at Zhonghechang was fully Chinese in project design and implementation. Sichuan province provided an annual subsidy for nursery work, and provided personnel for physical examinations, vaccinations and basic health care of local women and children. The Guomindang state invested in the project in part because the models might be useful, but also because it helped strengthen the nation and aid in the war effort. Zhonghechang helped the war effort in some direct ways, by providing haircuts and laundry services to soldiers conscripted from the local area when they passed through town. ${ }^{93}$

A report in the pamphlet from Wallace Grant Fiske, identified as "Chaplain 14th Air Force stationed in China," suggests how the wartime imperative for healthy citizens overlapped with the impulse for Christian service to reform habits. He observed a nursery class singing and noted, "Even though I could not understand their Chinese, I did know from their gestures that they were learning such lessons as the importance of keeping their bodies clean, drinking only boiled water, and ridding their homes of filth and flies." With clear admiration, Fiske added that the Ginling workers made home visits, conducted a program of nursing, and led "instruction in home-making, child-care, and sanitation." Fiske continued, "They know the home needs of these people and the friendly smiles and respectful bows when we walked in the streets testified to the confidence and esteem which everyone has toward them." He was greatly impressed with the work of Hsiung and Tsu. Of all the mission stations he had visited in China and India, he had not met "workers for whom I have greater admiration than these two consecrated labourers at Chung Ho Chang." They expressed their appreciation for the aid supplied by the Association of Universalist Women. "But," Fiske wrote, "before them I felt humbled and I know I should thank them for the privilege of giving us a share in this great Christian work." ${ }^{\prime 94}$

The work in Zhonghecheng is an example of how missionary ideas about domestic improvement were indigenised by Chinese women for strengthening

\footnotetext{
92 Hsiung Ya-na and Tsu Yu-dji, "A look at our work in China," in the Association of Universalist Women, "A Look at our work in China, sponsored under the auspices of Ginling College in Chung Ho Chang," Boston, 1945, from Hsiung, Ya-na folder, Graduate School Records, DRMC Cornell University Library Collection \#12-5-636.

93 Ibid.

94 Wallace Grant Fiske, "I saw our work in China," in "A Look at our work in China."
} 
China. Christian service was undoubtedly an important part of this work for Hsiung. She accepted that China was "backward" and needed better sanitation, improved childrearing methods, and modernised family practices. She felt it absolutely necessary to live among those being reformed and enlightened and to model the correct hygienic behaviour and religious belief as well. In a typescript found in her application materials for graduate study at Cornell she described how Ginling workers interacted with the local people.

We have become one of them, and we are their friends, yet they have discovered certain differences between us and themselves: we say grace or sing before each meal; we have two pairs of chopsticks for each person at the table - one to serve with and one to eat with; we use mosquito nets gathered into a round band at the top instead of square ones; we have foreign friends come visit us. However, these four differences make no gulf between us and the local people, they regard these dissimilarities as our peculiarities just has Brother Wang has a peculiar way of drinking his tea. ${ }^{95}$

The education, practices and beliefs of the Ginling rural service workers set them apart from the rural masses. Yet Hsiung claims the particularities of worship or efforts to avoid sharing germs were eventually accepted as quirks of individuals rather than ideas of foreign import. Hsiung was one of many in rural service who took their missionary teachers' messages of the significance of public health, cleanliness, better childrearing and Christian vision and made them seem Chinese.

Foreign missionary women had advanced notions of improving Chinese homes and women from the mid-nineteenth century. By the end of the war in 1945, the ideas of Christian service, rural education and domestic improvement were largely indigenised. Ginling leaders like Wu consistently advocated the idea that educated women, like Ginling graduates, should be particularly responsible for the welfare of China's disadvantaged women and children. The Guomindang Nationalist state provided some financial assistance in the realm of child welfare, social education and public health. During the war the Nationalist party also planned for the welfare of the Chinese people in the longer term. ${ }^{96}$ Ginling women pushed this modernising agenda and found ways to fund it. They courted and received foreign aid money, not just from mission bodies but from institutions like the United Nations Relief and Rehabilitation Association (UNRRA). And it was Chinese women, many of them trained in missionary

95 Hsiung Ya-na, "Two years at Chung Ho Chang, a backward glance," n.d., found in the folder of Hsiung, Ya-na, Graduate School Records, DRMC, Cornell University Library Collection \#12-5-636.

96 Tehyun Ma, "A Chinese Beveridge plan: the discourse of social security and the post-war reconstruction of China," European Journal of East Asian Studies 11(2) (December 2012): 329-50. 
institutions, who designed and organised these programs that operated on the continuing assumption that the educated elite knew what was best for the Chinese masses.

\section{Ginling's post-war social service}

Once back on their Nanjing campus after the Sino-Japanese war, Ginling College continued to train its graduates to reform Chinese homes and family life. Wu wrote in a report to the Board of Directors in 1946, "There are special projects to which Ginling should give attention, such as the re-establishment of the Education Department, a course in Personnel Guidance, Extension work into home through the Home Economics Department and the Child Welfare Program." ${ }^{97}$ As with the work in the wartime rural service centres, Ginling students were encouraged to diagnose Chinese family life with an eye toward meeting the needs of China. Accordingly, students in one child welfare class noted that many children "are not really taken care of by their parents so they are trying to teach good habits, [like] cutting nails, brushing teeth, and cleaning hands." 98 Their solution was continued attention to nutrition, hygiene and habit formation. Other child welfare students expanded on reasons for children's problems. They noted in shorthand: "Breakdown of large family system partly responsible for mental problems - no one now to train young mothers. Large families will probably never be restored - necessary to cope the problem [sic]." ${ }^{\prime 99}$ To help children with behavioural problems, a Ginling professor of child welfare ran a child guidance clinic in Nanjing. One of her goals was to "help children with personality problems so that they may become healthy adults, both mentally and physically, and useful citizens." ${ }^{100}$ As in Renshou, modification of behaviour was a vital factor for national salvation. At this time, the social problems were expressed in the language of a growing mental health field rather than one of morality. The underlying assumptions remained the same- that educated Chinese women should intervene in the family life of others.

As during the war, in the post-war period there continued to be a lack of trained female personnel who understood modern standards of home economics or social work. Wu continued to push for graduate training abroad, and mobilised her foreign and domestic contacts to help place Ginling graduates. The importance of foreign knowledge in developing a pool of talented Chinese

\footnotetext{
97 "Report to Board of Directors of Ginling College," 9 November 1946, SHAC RG 668/214.

98 "Ertong fuli shiyan suo gongzuo baogao," (Child Welfare Experimental Center Work Report), 1945, SHAC RG 668/10.

99 "The scope of the child care field in China," outlined by Chinese Students at the Vassar Summer Institute for Family and Child Care Services in War time (July 1948), SHAC RG 668/13.

100 Ming-sin Hsueh Tang, “Report on child guidance service, 1946-1947," SHAC RG 668/13.
} 
leaders may be illustrated by the case of Anna Hsiung. Both Irma Highbaugh, who worked with Hsiung at Zhonghechang, and Wu wrote her strong letters of recommendation to attend Cornell University. ${ }^{101}$ During the war Wu often wrote about the need to train Chinese women for service so that women's issues would be addressed. Highbaugh echoed these sentiments when she wrote, "I should hope that Cornell University will be able to admit her and to provide for her whatever scholarships may be available to foreign students. I trust that in this way, the splendid service which the university has given to China through agricultural and technical training of many of her men, may thus be extended to one of her very able women." ${ }^{102}$ For both of these Christian educators, Chinese women were as capable of making contributions to China equal to those of men.

On the basis of these and other recommendations, Hsiung entered Cornell as a candidate in Child Development and Family Relations in 1946. Hsiung wrote to Ginling soon after her arrival in the United States that she felt quite at home. "From my trip and my short experience in America, I understand that God has planned well for me and this friendliness of the Americans impressed me deeply." 103 She completed her M.A. thesis, "Study of family life in preschool children in a Chinese rural town," in 1947. It was largely based on her work at Zhenghechang and provided ideas about how to plan for future social wellbeing in China's countryside. ${ }^{104}$ At the behest of Wu, Hsiung returned to China to join the staff of Ginling's new rural service station later that year. ${ }^{105}$

Ginling's new rural service station was called Shwen Hua Cheng (Chunhuazhen in Jiangning County) and was approximately twelve miles south east of Nanjing. ${ }^{106}$ The area had been occupied by the Japanese, and, according to one report, at least 3,000 families badly needed "reconstruction."107 Funding came from the Ministry of Social Affairs, Social Welfare Committee of United Service to China, and the women of the American Universalist Church. ${ }^{108}$ The United Nations Relief and Rehabilitation Association funded a feeding

101 Irma Highbaugh to Dean Sarah Blanding, Department of Home Economics, Cornell, March 9, 1946, folder of Hsiung, Ya-na, Graduate School Records, DRMC, Cornell University Library Collection \#12-5-636; Wu Yifang to Sarah Gibson Blanding, 14 March 1946, UBCHEA RG 11 box 137-2757.

102 Irma Highbaugh to Dean Cunningham, Graduate School, Cornell University, 9 March 1946, folder of Hsiung, Ya-na, Graduate School Records, DRMC, Cornell University Library Collection \#12-5-636.

103 Hsiung to Mrs. Mills, 23 September 1946, UBCHEA RG 11 box 137-2757.

104 "Students from outside the continental United States who are studying or who have studied home economics in United States Colleges," Omicron Nu Magazine 26(4) (Spring 1949): 36-47, p. 45.

105 Hsiung to Mrs. Mills, 26 October 1947, UBCHEA RG 11 box 137-2757.

106 In Chinese it is "Chunhuazhen" (淳化镇) but in English language documents it is "Shwen Hua/Shuen Hwa Cheng." See Ginling College rural service station at Shwen Hua Cheng (1947-1948), SHAC RG 668/11; Tsu Yu-dji, "Report on rural service station at Shuen Hwa Cheng, 1947-1948," SHAC RG 668/14; Li Zhenkun 李振坤, “Chunhuazhen de xiangcun fuwu zhan" (The Rural service station at Chunhuazhen 淳化镇的乡 村服务站), in Yongjiu de sinian (Memory Forever) 永久的思念, ed. Jinnüda xiaoyouhui (Ginling Women's College Alumnae Association), Nanjing: no publisher information available, 1993, p. 114.

107 Ginling College rural service station at Shwen Hua Cheng (1947-1948), SHAC RG 668/11.

108 Tsu Yu-dji, “Report on rural service station at Shuen Hwa Cheng, 1947-1948," SHAC RG 668/14. 
station for children and organised handicraft work of sewing, cross stitch and paper cut-outs. ${ }^{109}$ According to a later account, Ginling helped sell these items and children's toys abroad to help "open new possibilities for economic advance of the rural population." 110 The social service conducted at Chunhuazhen was much like that at Renshou and Zhonghechang, with emphasis on bettering the lives of women and children with economic advancement, literacy, child welfare and domestic improvement work all on the agenda. One report noted successes in a two-week training course in family life: "The results of the training were apparent: the mothers attempted to keep their house cleaner and they tried to use better methods in training their children."111

In the post-war period, the Christian missionaries' vision of domestic improvement, particularly in rural areas, remained a powerful one even after the foreign missionaries were mostly absent from the scene. Their influence remained through funding and the transmission of the ideologies of domestic reform imbued by their Chinese students. In the case of Ginling College, Chinese women became indigenous bearers of what they believed to be superior knowledge and domestic modernity that would best serve China.

\section{Conclusion: After the revolution}

In the immediate aftermath of the Communist victory, Ginling leaders were still hopeful that their forms of social service might continue to serve in the development of China. In 1950, a Chinese child-welfare professor noted, "We have worked hard to keep up the college standards and to prove to the new society at large the real spirit of service to people for which the college stands."112 Despite Ginling's efforts to maintain the college as a place to train Chinese women for service, the new regime dismantled all the Christian colleges in their educational reorganisation of colleges and universities in 1952. Wu eventually backed away from her efforts to develop social service at Ginling, damning the social service work, such as handicraft efforts at Renshou, as poisonous. Wu claimed that these American-funded efforts to provide a livelihood to Chinese women made those involved feel that "only America was good." Wu argued in 1973, "The poison in the so-called cultural aggression lay in having us take the poison without knowing it." ${ }^{\prime 13}$ But in claiming ignorance of cultural aggression

\footnotetext{
109 Ginling College rural service station at Shwen Hua Cheng (1947-1948).

110 Li Zhenkun, “Chunhuazhen de xiangcun fuwu zhan," p. 114.

111 Ginling College rural service station at Shwen Hua Cheng (1947-1948).

112 Ming-Sin Hsueh Tang to Ginling College Committee, 26 October 1950, UTS, MCT Papers, box 7, folder 43.

113 Chao Hao-sheng, typescript of interview of Yi-fang Wu, p. 6.
} 
at the time, $\mathrm{Wu}$ also denied her own role, and the role of other Chinese women, in forwarding a Christian vision of service and in envisioning a better Chinese future.

There are many reasons for this later critique of Christian social service as "cultural aggression." The activities were associated with the bourgeois elite and they rested on foreign connections. Many Chinese leaders were foreign trained, and often projects received material support from abroad. Another strike against service efforts was that social service providers claimed to know what the Chinese masses "needed" without really consulting the masses. This was opposed to "learning from" the masses. Finally, as Wu pointed out in her 1973 self-criticism, "In the past I thought it was my job to run a school, and to let students do the serving of society, but this didn't fundamentally change any of China's problems." ${ }^{\prime 14}$ Social service only ameliorated conditions caused by the capitalist system. In $1973 \mathrm{Wu}$ argued that only through revolution could the structures of Chinese society be altered to provide greater opportunities for all.

As the Chinese state thinks about how to best meet the needs of its people in a post-socialist age, it seems a good time to re-think the work of women reformers from the first half of the century. Despite the later negative view of social service, the experiences of educated Chinese women involved in these projects suggests a significant way that they envisioned a changed and reformed society in the Republican period. As I have shown in this chapter, Chinese women at Ginling College embraced the scientific vision of progress and enacted family betterment campaigns taught by their missionary teachers. Chinese leaders, like $\mathrm{Wu}$, developed transnational networks to exchange ideas about relief projects, solicited funding for those projects, pushed the Chinese state to meet their responsibility to the Chinese people, and worked with the Nationalist party. Through these efforts, educated Chinese women made the missionary ideals about social service their own.

The projects that women designed to improve the lives of disadvantaged women perpetuated ideas that women should serve society in ways different from men. Women's vision of service rested on the assumption that they were best suited to effect family reform, women's development and improvement of child welfare. Ginling rural service workers and Wu often, but not always, stressed what they could do to improve the lot of all Chinese women by encouraging correct management of homes, rationalisation of production, better hygiene and improved childrearing. They embraced the idea that Chinese families needed to be restructured, and that efficient and scientific approaches to domestic life that were circulating globally could be learned and applied to solve China's social problems. 
At the same time, the knowledge, skills and training in how to improve Chinese families acquired by Ginling women both enabled them to gain authority over others seen as less advanced than themselves and empowered them to suggest the ways that the state might improve the conditions for less privileged members of society. Like the missionaries who constructed images of backwards and heathen Chinese, Ginling women constructed a group of individuals less advanced than themselves - rural Chinese women, who needed saving and guidance out of a condition of ignorance. Educated Chinese women perpetuated discourses about Chinese backwardness and benighted Chinese womanhood. Wu trained a cohort of Chinese woman leaders who could rise to the challenges of Chinese backwardness. As she realised later, she had not worked for longterm political change. She did not push her graduates to work in the highest levels of party leadership. For Ginling administrators and students like Wu Yifang, women's leadership meant improving the lives of Chinese women and children and recommending policy changes to the state. Leadership meant that leading Christian social service efforts rather than serving alongside men in national policy-making bodies was the most significant way that educated women should serve Chinese society.

\section{Acknowledgements}

I appreciate Margaret Jolly's and Hyaeweol Choi's efforts in bringing the contributors together, for their comments on earlier drafts of this chapter, and for their work in tying this volume together. I also thank Carolyn Brewer for her careful editing of this chapter. The author is grateful to archivists in the United States and the People's Republic of China for allowing access to archival materials on Ginling Women's College, particularly Martha Smalley at the Yale Divinity School. Each collection is followed by the acronym used in the endnotes. Two collections were consulted in 1990 to 1992, the Matilda Calder Thurston papers in the Burke Library Archives (Columbia University Archives) at Union Theological Seminary, New York (UTS, MCT Papers) and the Presbyterian Historical Archives, Philadelphia, PA (PHA), and as a result their record numbers may not reflect more recent cataloguing. The following archival collections were consulted after 2000: Ava Milam Clark Papers of Oregon State College Archives housed at Oregon State University in Corvallis, Oregon (AMC Papers); Division of Rare and Manuscript Collections, Cornell University Library, Ithaca, NY (DRMC); the Second Historical Archives of China in Nanjing, China (SHAC); and papers on the United Board for Christian Higher Education in Asia, Record Group 11, at Yale Divinity School Archives, New Haven, Connecticut (UBCHEA). 
This text taken from Divine Domesticities: Christian paradoxes in Asia and the Pacific, edited by Hyaeweol Choi and Margaret Jolly, published 2014 by ANU Press, The Australian National University, Canberra, Australia. 